\title{
P. Meera Khan
}

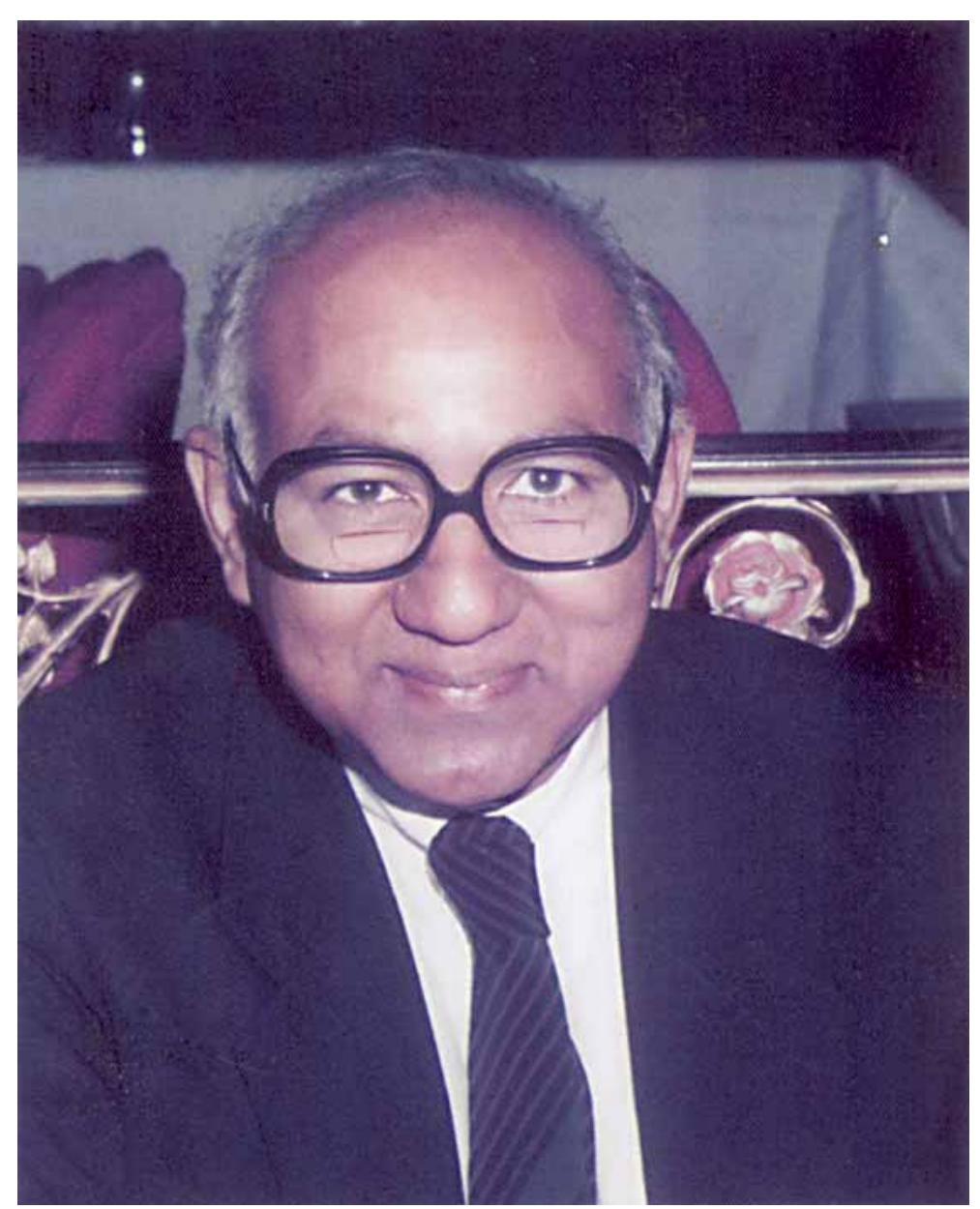

This special issue of Cytogenetics and Cell Genetics acknowledges both the scientific contributions and compassionate humanitarian values of Prof. Dr. P. Meera Khan who died on April 1, 1998. Meera Khan, known to his friends as Meera, had worked for more than 30 years in the Department of Human Genetics in Leiden in a career that spanned many aspects of human genetics, including important contributions to somatic cell genetics, gene mapping, isoenzyme studies, gene nomenclature and, during the last 15 years, the study of familial colon cancer. Shortly following his death, an international symposium over the impact of molecular genetics on the clinical treatment of colon cancer was held in Leiden. This symposium had been scheduled long before it was realised that Meera was terminally ill and had originally been intended as a farewell for Meera's retirement. In complete keeping with the ordered way Meera ran his professional and private life, one of his last wishes before he passed away was that the symposium should take place as planned. It is fitting that this memorial issue large- ly comprises articles based on presentations made at the symposium plus others submitted by close friends and colleagues which characterize areas of research that Meera was involved with over the years.

Many of the contributors to this issue have included their own personal tributes to Meera. There is an almost universal reference to the excellent scientific standards he espoused and frequently to the gentle but firm and dignified way he dealt with the world around him. Many, myself included, found him difficult to know. Meera was a very private person. He enjoyed viewing the world but did not like being observed himself. Perhaps only his wife Prabha understood him completely. It was she who shared Meera's hopes, successes and failures and only she knew just how much dedication Meera gave to his career. However, for everyone who knew him, the most over-riding feeling about Meera was one of respect, both for his scientific and life values. 
Meera was very much guided by role models in his formative years. He was born into a middle class background in rural Andhra Pradesh. His father was a general practitioner and although he died when Meera was still very young, Meera's positive remembrance of those times was sufficient to convince him to become a medical practitioner himself. An older brother introduced Meera to classical Indian history and culture; this remained an abiding interest of Meera up to his death. His school period was noted for the rapid progress and intellectual prowess of the young pupil. Meera went on to college to read biology, chemistry and physics where he met his wife to be, Prabha. Their subsequent marriage was touched by the fervent religious tensions of India of the mid 1950s, which were still running high following partition. Meera came from an Islamic and Prabha from a Hindu background and some family members tried to prevent the marriage. However, true love prevailed, the young couple resisted convention, married, set up home and, shortly after, started a family. During this period Meera entered the Andhra Medical College, Visakhapatnam. During the latter part of his study he was privileged to attend a lecture by J.B.S. Haldane on high altitude physiology. Subsequently, Meera contacted Haldane via one of Haldane's associates and was invited by Haldane to the Indian Statistical Institute in Calcutta for discussions on human genetics and the genetic determinants of disease resistance in human populations. Haldane recognised in Meera someone with the ability and interest to set up such investigations and in 1959 convinced him to commence research on the relationship between consanguinity and infectious disease in his "spare-time" as house surgeon. Following his residency Meera was further encouraged and also financed by Haldane to gain more experi- ence in carrying out genetics studies with Siniscalco in Naples and Sardinia, with a view to setting up similar studies in India. The close relationship between Meera and Haldane continued up to Haldane's death in late 1964 and was described by Meera in an article published in Bionature in 1993. In that article Meera recounts what must rank as one of the strangest events in a young man's scientific career. Meera was the only medically qualified person in Haldane's immediate ring of colleagues and Haldane requested Meera to attend to the dissection of his body when he died, so that his skeleton and other body parts could be made available to science. In Haldane's own words "I hope that I have been of some use to my fellow creatures while alive, and see no reason why I should not continue to do so when I die". Meera carried out Haldane's request to the letter. When Haldane realised he was suffering from bowel cancer, he wrote to Meera about his condition and proffered "I venture to hope that you and your wife will escape it (cancer) and live long enough to get a proper chemotherapeutic or serotherapeutic treatment if you do". Ironically, this was not to be and Meera Khan, himself, also died of incurable cancer some 35 years later.

Meera leaves a very tangible legacy. His genes go on through his children and grand-children. His scientific work and values have been adopted by many generations of graduate students. In the words of one of those young scientists who attended the symposium, "Meera Khan was my role model".

July 1999

Peter Pearson

P. Meera Khan: Some of my reminiscences of Professor J.B.S. Haldane. Bionature 13:95-104 (1993). 